\title{
Universidad Social Capital and the Competitiveness of Entrepreneurs: A Review of the Literature and Proposals
}

\author{
Mariel Fornoni, Francisco Mas-Verdú, Domingo Ribeiro Soriano \\ and Salvador Roig Dobón, \\ Universidad Nacional de Mar del Plata, Buenos Aires, Argentina \\ Universidad Politécnica de Valencia, Valencia, Spain \\ Universidad de Valencia, Valencia, Spain \\ Universidad de Valencia, Valencia, Spain
}

\section{Introduction}

Sources of value creation in organizations are normally separated into three different types: financial capital (money, bank reserves, lines of credit); human capital (natural qualities such as intelligence and good health combined with skills acquired via formal education in the professional field); and social capital - relationships with colleagues, friends or contacts through which opportunities open up for using financial and human capital (Burt 1992).

In management literature, the concept of social capital has received notable attention over recent years. The underlying basis of the theory of social capital rests on the idea that social networks constitute a fundamental resource for doing business (Burt 1992; Nahapiet and Ghoshal 1998). These networks allow entrepreneurs to expand their field of action, to become more efficient and to access exclusive opportunities (Batjargal 2003). Equally, for some workers, their social capabilities have allowed them to obtain a good job or to find a better one (Granovetter 1973; Ibarra 1995; Lin and Dumin 1986). Social capital can lead to professional success for mid or top level managers by strengthening their degree of power and status (Belliveau et al., 1996; Burt 1992, 1997; Leana and Van Buren 1999). 
The essential question asked in this study is "How can social capital become a competitive tool for entrepreneurs". The answer lies in showing how their own networks can provide the value and competitiveness that entrepreneurs need for their business projects.

This chapter is structured as follows: firstly, a review of the concept of social capital is presented. Secondly, the sources, types and levels of social capital are discussed from different approaches, as well as different means of measuring social capital with a view to associating different levels of social capital with the performance of entrepreneurial projects. The chapter ends with a series of proposals and conclusions.

\section{What is Social Capital?}

The topic of social capital has come to represent a line of research of enormous interest for economists, political scientists and sociologists in recent years. An ever-increasing number of research articles, book chapters, entire books, citations and Internet sites in the last 10 years bear witness to this fact, though this growth has not been equalled by a greater clarity of the concept. As Paldam puts it, "social capital is close to becoming a concept common to all branches of science ..." (2000, p. 631).

The term social capital was first used in a study by Hanifan in 1916 . He argued that performance in rural schools could be attributed to "...those tangible substances that count for most people in their daily lives: good will, commitment, kindness and social interaction between individuals and families that make up a social unit..." (1916, p. 130).

However, without a doubt, one of the major precursors was James Coleman $(1988,1990)$ with his seminal works "Social capital in the creation of human capital" and "Foundations of social theory". In his approach, the social context is characterized by the organization of relations between the actors, in other words, social structures. These structures obtain the resources that constitute social capital. For Coleman, capital does not come from a decision that seeks to make profits in the future, but from other activities, thus making it more of an external factor that enables the actions of individuals (1988, p. 118).

The clearest example laid down by Coleman is the way that the diamond market in New Cork functions. This example contains all the elements of Coleman's perception of social capital: the existence of profit more easily obtained through interaction based on trust (economy of transaction costs), a relatively closed community, sufficiently strong relationships for opportunist behaviour to be rejected and diffused, and unwritten rules concerning honesty associated with strong enough sanctions, such as exclusion from the community. 
Although Coleman does not contribute to the development of the concept, his works are considered to be pioneering.

Another of the great precursors of this topic of social capital is Robert Putman. A Harvard politologist, and fine public speaker, he had the ability to link the concept of social capital with the more up-to-date problems of public policy, and became one of the authors that has contributed most to the diffusion of the concept. From among his many contributions, the first "Making Democracy Work", in 1993 (Putman et al., 1993), constitutes seminal research on the conditions under which political institutions obtain performance. In his study, he presents the results of research in the 1970s on the institutional performance of 20 Italian regions.

In 1995, in his study "Bowling alone: America's declining social capital", Putman addresses three important ideas: mapping the symptoms of the decline of social capital, showing the benefits associated with the possession of a high degree of social capital and taking action that will foment research into social capital to continue. The underlying conceptualization of his work can is encapsulated in the following lines: “... social capital refers to characteristics of the social organization such as networks, norms and social trust that enable coordination and communication, enhance reputations and thus allow the dilemmas of collective action to be resolved (...) finally, dense networks of interaction develop within the participant a feeling of being oneself, developing the 'I' in 'us', leading the participants to experience collective advantages" (1995, p. 67).

In his work "Bowling Alone: the collapse and revival of American community" (2000), Putman proposes a different definition from the one that appears in the 1993 study, as he brings the same notions into play but in reverse order, thereby eliminating an immediate reference to the beneficial effects: “... Just as physical or human capital can increase productivity (individual and collective), social contacts can also affect the productivity of individuals and groups" (2000, p. 18).

Another important figure at the forefront of research into social capital has been Francis Fukuyama (1995), who presents a remarkably simple theory: a nation's capacity to develop the institutions that will drive it forward depends upon its population's inclination for trust, whose origin can be found in values that are inherent in that nation's culture. For Fukuyama, social capital is defined as "... an asset born from the predominance of trust in a society or in certain sectors of society... Social capital differs from other forms of capital in that it is normally created and transmitted through cultural mechanisms such as religion, tradition or past behaviour" (1995, p. 36). Fukuyama's work fundamentally focuses on dividing the world's nations into two types of countries: high trust nations 
and a group of countries with a majority of small family or state-owned businesses, labelled as low trust countries.

Pioneering authors refer fundamentally to a macro level of analysis, i.e., one that addresses the social capital that forms the structure of relationships in society, leaving, on the one hand, a system of trust, institutions, norms and social networks and, on the other, organizations that make up the interactions of agents in a social context. All these factors constitute an asset for the individual and collective production of social welfare.

However, social capital must also be associated with other levels of analysis, where its composition is highly important: firstly, in the framework of firms and organizations, where a particular composition of social capital can optimize growth; and secondly, for individual social capital and, in our specific case, for the social capital of the entrepreneur.

When talking of social capital at an organizational level, we refer to capital that is generated in the relationships established by the members of an organization for collective action and can be observed at an individual level between firms, between and within units and firms.

A pioneering study in relation to intrafirm organizational social capital was provided by Nahapiet and Ghoshal (1998), who analyze the advantages for an organization that has the capacity to create and share knowledge. For these authors, social capital enables the creation of new organizations of intellectual capital. Depending on their ability to construct denser social capital, they will be able to obtain advantages over other firms in terms of creating and sharing intellectual capital. This study constitutes a suitable framework for understanding the creation of value in networks within a firm. Social capital thus considers the network and the assets that can be mobilized through that network (Bourdieu 1986; Burt 1992).

Tsai and Ghoshal (1998) subsequently applied the framework developed by Nahapiet and Ghoshal to apply it to a multinational electronics firm. They analyzed relations between 15 business units of the multinational, investigating four resources produced by the network: information, products, staffing and support services. Social interaction, a manifestation of the structural dimension of social capital, and trust, a manifestation of its relational dimension, were positively related to the degree of the exchange of the resource in question, which had a significant effect on product innovation. Figure 1 synthesizes the conceptual model applied by these authors in their research.

Leana and Van Buren (1999) studied social capital among firms, particularly in terms of employment practices. They introduce the term organizational social capital, at the same time as developing a model on its components and consequences. 


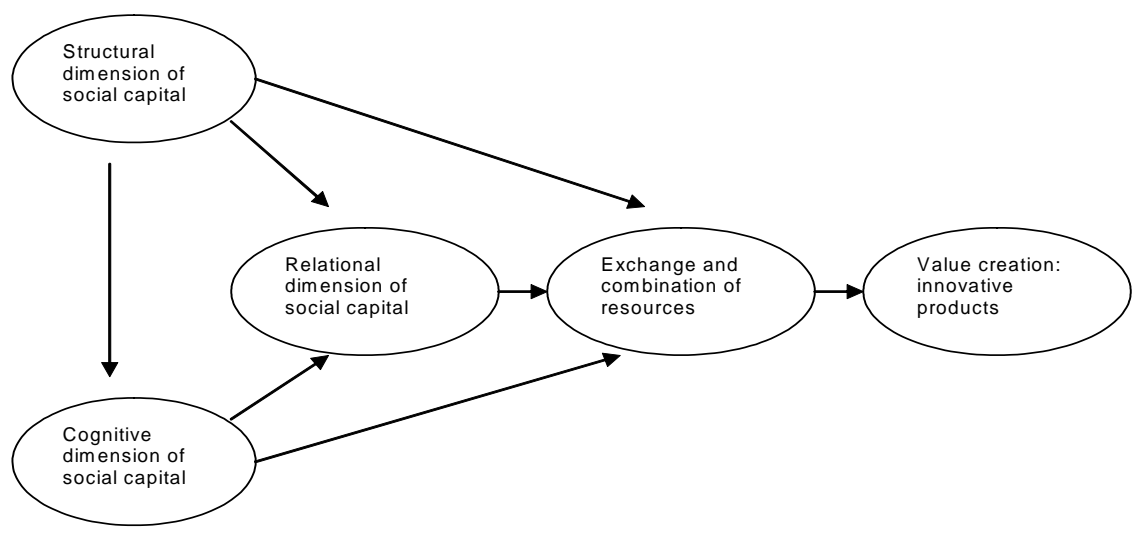

Fig. 1. Model of social capital and value creation from the model of Tsai and Ghoshal. Source: Adapted from Tsai and Ghoshal (1998)

The different streams that analyze the concept of social capital can be placed into two groups: (a) those that define it as a public value, where the benefits arise from the social structure itself (Coleman 1988; Fukuyama 1995; Putman 1993); (b) those that consider it to be a private value whose results are for the benefit of the owner of that social capital (Burt 1992; Lin et al., 1981).

Leana and Van Buren define organizational social capital as an "...attribute of the organization..." (1999, p. 540), i.e., as an asset that may benefit both the organization and its members. Despite the fact that these authors also ponder the costs associated with the creation and maintenance of social capital, this aspect is not analyzed through empirical studies.

From amongst the more notable research on organizational social capital at an interfirm level, it is essential to mention the work of Uzzi (1997), who develops a systematic understanding of the articulation of networks in the organization. Uzzi carried out an ethnographic study by analyzing 23 entrepreneurial firms in the women's clothing market in New York, where competition is extremely high, there are thousands of firms, and the barriers to entering the sector are relatively few. The conclusions of this study show that relations have three main components that regulate the expectations and behaviour of exchange between the different parties: trust, the transfer of detailed information and resolving common problems.

Table 1 summarizes some of the research on the creation of the value of social capital within the framework of organizations. 
Table 1. Summary of research on the creation of the value of organizational social capital

\begin{tabular}{|c|c|c|c|c|}
\hline Researchers & $\begin{array}{l}\text { Sources of value } \\
\text { creation }\end{array}$ & $\begin{array}{l}\text { Type } \\
\text { of network }\end{array}$ & Industry & Size \\
\hline $\begin{array}{l}\text { Nahapiet and } \\
\text { Ghoshal (1998); } \\
\text { Tsai and } \\
\text { Ghoshal (1998) }\end{array}$ & Product innovation & Intra & Electronics & $\begin{array}{l}\text { Multi- } \\
\text { national }\end{array}$ \\
\hline $\begin{array}{l}\text { Leana and Van } \\
\text { Buren (1999) }\end{array}$ & $\begin{array}{l}\text { Flexibility in the } \\
\text { workplace } \\
\text { Collective organi- } \\
\text { zation } \\
\text { Intellectual capital } \\
\text { intellectual }\end{array}$ & Intra & $\begin{array}{l}\text { No empirical } \\
\text { study }\end{array}$ & \\
\hline $\begin{array}{l}\text { Yli-Renko } \\
(1999)\end{array}$ & $\begin{array}{l}\text { High performance: } \\
\text { new product devel- } \\
\text { opment, reputation } \\
\text { and technological } \\
\text { advantages }\end{array}$ & Inter & $\begin{array}{l}\text { Pharmaceutical } \\
\text { industry, com- } \\
\text { munications, } \\
\text { electronic } \\
\text { instruments }\end{array}$ & $\begin{array}{l}\text { Sales of } \\
\text { between } 5 \\
\text { and } 26 \\
\text { million } \\
\text { pounds }\end{array}$ \\
\hline $\begin{array}{l}\text { Walker et al. } \\
\text { (1997) }\end{array}$ & Growth in industry & Inter & Biotechnology & Start-ups \\
\hline Uzzi (1997) & $\begin{array}{l}\text { Information } \\
\text { exchange } \\
\text { Learning }\end{array}$ & Inter & Fashion industry & $\begin{array}{l}\text { Medium- } \\
\text { sized and } \\
\text { large }\end{array}$ \\
\hline $\begin{array}{l}\text { Zaheer, } \\
\text { McEvily and } \\
\text { Perrone (1998) }\end{array}$ & $\begin{array}{l}\text { Avoiding conflict } \\
\text { Reduction of } \\
\text { negotiation costs }\end{array}$ & Inter & $\begin{array}{l}\text { Electrical } \\
\text { equipment for } \\
\text { manufacturers }\end{array}$ & All \\
\hline $\begin{array}{l}\text { Goes and Park } \\
\text { (1997) }\end{array}$ & Innovation & Inter & $\begin{array}{l}\text { Hospitals for } \\
\text { the treatment } \\
\text { of acute patients }\end{array}$ & All \\
\hline Singh (1997) & $\begin{array}{l}\text { Moderation of } \\
\text { technological } \\
\text { changes in high tech }\end{array}$ & Inter & $\begin{array}{l}\text { Software indus- } \\
\text { try for hospitals }\end{array}$ & All \\
\hline $\begin{array}{l}\text { Shan, Walter } \\
\text { and Kogut (1994) }\end{array}$ & Innovation & Inter & Biotechnology & Start-ups \\
\hline $\begin{array}{l}\text { Deeds and Hill } \\
(1996)\end{array}$ & $\begin{array}{l}\text { Acceleration of } \\
\text { product development }\end{array}$ & Inter & Biotechnology & All \\
\hline
\end{tabular}

Source: Author's own work

As opposed to the approaches mentioned above, other studies have attempted to analyze the motivations of individuals for using social capital and for investing in its use. From an individual perspective, the emphasis lies on the potential benefits individuals may acquire from their network of formal and informal ties with others. 
The leading author of this line of research is Ronald Burt (1992), beginning with his study "Structural holes, the social structure of competition". In this study, he considers social capital to be a private value, pertaining to each individual. This study by Burt (1992) also clearly shows the role played by particular points in a network when creating competitive advantages. These are points where the nodes and their occupants converge with information that is unlikely to be accessed by other means. They represent valuable capital for those that find themselves in a particular structural position. Burt's study (1992) explains why an actor that occupies a point in a network with its corresponding series of contacts, may have a competitive advantage over others, obtaining better returns for their investments. The agent thus "... describes the way in which social structure generates imperfect competences, creating entrepreneurial opportunities for certain actors and not for others" (1992, p. 8).

In short, social capital appears as a metaphor for advantage (Burt 2001). When certain individuals, or groups of individuals, obtain better returns for their efforts, it may be supposed that such inequality is the result of the fact that such people are more skilled or more highly qualified. The social capital approach suggests that an individual, or group of individuals, has better connections (Burt 2001). In this sense, social capital becomes a contextual complement for human capital.

Burt's theory (1997), supported by the more recent article by Bolino et al. (2002), contributes contingent value to social capital. In other words, decisions taken by individuals have a fundamental impact on the development of social capital and the behaviour of members in an organization founded on honesty, obedience and social participation and contribution to the development of that organization.

Therefore, from a review of the scientific literature on social capital, research can be classified into three levels: (1) some research focuses on a macro level, with regard to society, country or region (2) a second group deals with a meso or organizational level (3) lastly, the third grouping adopts an individual or micro level at which to analyze social capital. The graphic below (Fig. 2) is a synthesis of these groups of studies, characterized according to the classification of the level of analysis.

In addition, it should be stated that, in recent years, a stream of research has emerged that attempts to explore the possible negative or undesirable effects caused by certain forms of social capital.

Portes (1998) shows that certain social networks, such as those developed by terrorist or mafia groups, can use social capital for destructive ends. This author also presents other examples of possible negative consquences of social capital such as excessive demands on members or taking advantage of the success of a particular group via restrictions on individual 


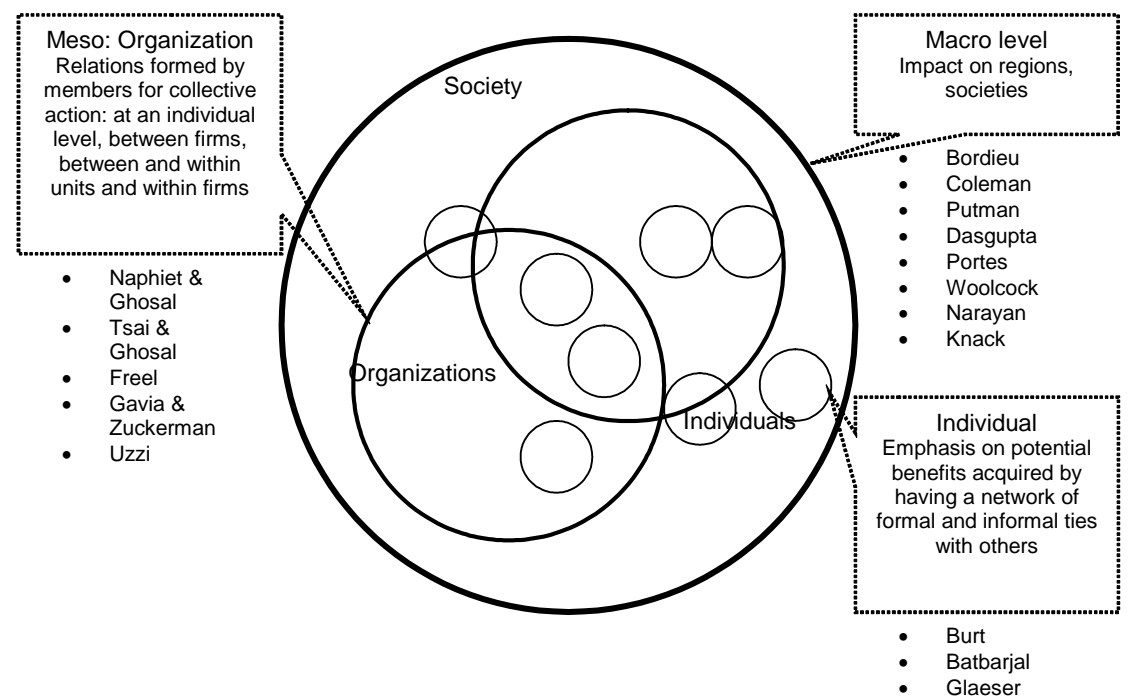

Fig. 2. Summary of levels and contributions to social capital. Source: Author's own work

freedom and the possible tendency to place certain norms at a level that can hinder the full participation in their social lives of members of a particular oppressed group (1998, p. 15).

\section{Social Capital, can it Really be Considered a Type of Capital?}

Different outlooks can be found with regard to this question. Indeed, some prestigious economists see the concept of social capital with some scepticism, for Arrow (2000), Dasgupta (2000) or Solow (2000).

Solow (2000) is extremely critical of the concept and the way it is used; he not only stated that the concept of social capital is inapplicable to economic fields, but also that, hitherto, only vague ideas and the occasional empirical study have been produced. Generically, "capital" is an action resulting from production factors from which productive returns can be expected within a certain time, which cannot be said of social capital, and thus its conceptualization as capital is a poor analogy. Solow claims that "...In relation to social capital, trust... there is a profitability in terms of added productivity. But can we really think of social capital as a type of capital? How might an accountant measure and accumulate this capital? I have never asked so many rhetorical questions in all my life..." (2000, p. 19). 
Arrow (2000) maintains that the metaphor of capital should be abandoned within the context of the notion of "social capital", as the term "capital" implies three aspects: a length of time; a deliberate sacrifice made in the present in order to obtain future advantages; and alienability, This last concept cannot be applied to social capital. He also believes that social networks are essentially formed for reasons other than economic ones, aside from the value that their participation in the network may represent (2000, p. 17).

Some researchers claim that social capital can be invested in with the expectation that it will generate benefits in the future, in just the same way as other types of capital do, although perhaps with more uncertain returns (Putman 1995). Moreover, just as happens with other types of capital, social capital can be appropriated (Coleman 1988) and converted (Bourdieu 1986), for example, in cases where social capital can be transformed into another type of capital thanks to a position held in a particular network that provides both economic advantages as well as others. It will, of course, be less liquid than other forms of capital, but in a similar way to other types, social capital can be substituted or complement other resources (for example, reducing transaction costs).

Similarly to human (though not economic) capital, social capital needs upkeep and does not possess a foreseeable indication of depreciation. Social capital can become devalued both by over-use and by a lack of it, and in some cases it can become obsolete due to influential contextual changes (Adler and Kwon 2002).

Other researchers, though, hold a favourable view of regarding social capital as another type of capital (Glaeser et al., 2000; Knack and Keefer 1997). As Grootaert and Van Bastelaer (2002) point out “... it is the only form of capital that cannot exist at the heart of a Robinson Crusoe-style economy, at least until the arrival on the island".

In his latest study, "Social Capital, a theory of social structure and action", Lin (2001), places social capital within the family of capital theories (classical and neo-classical theories). The evolution of capital theory in the last four decades has paved the way for a new theory labelled the neocapital theory, which includes human, social and cultural capital. "Human capital, which supposes that capital can rest on individual labour, goes all the way back to Adam Smith, who included all acquired, useful capabilities in a country's population as part of its capital (1937)" Lin (2001, p. 9).

Table 2 shows some of the differences between economic capital and non-economic capital, which includes social capital. 
Table 2. Differences between economic and non-economic capital

\begin{tabular}{lll}
\hline Characteristics & $\begin{array}{l}\text { Economic capital } \\
\text { (financial, physical) }\end{array}$ & $\begin{array}{l}\text { Non-economic capital } \\
\text { (human, social) }\end{array}$ \\
\hline Control & Ownership & Shared \\
Rationale & Speculation & Social (genuine) \\
Tangibility & Tangible & Intangible \\
Transferability & Transferable & Non-transferable \\
Dynamics & Static & Dynamic \\
Duration & Decreases with use & Increases with use \\
\hline
\end{tabular}

Source: Author's own work

Summing up, this section could be concluded by stating that, in our opinion, in light of the review carried out, social capital does enter into what might be called the heterogeneous family of types of capital (Arrow 2000). Whether this is a correct assumption or not, the specificities of this capital require the development of "ad hoc" methodologies in order to carry out measurement and analysis.

\section{Measurement of Social Capital}

The concept of social capital has undergone a notable evolution, largely due to empirical verification that associates the presence of a large stock of social capital with diverse, positive social and economic results. However, paradoxically, there is no consensus of opinion on how to carry out these assessments, a difficulty that is not unlike that experienced by the field of social sciences.

The measurement of social capital has, in fact, become a challenge in recent times, so much so that the OECD and the World Bank have taken the initiative of organizing an international working group with the aim of reaching a consensus on a series of indicators that will allow them to obtain a homogenous measurement. Such a task is hindered by the multidimensional character of the concept, which incorporates different levels and units of analysis and by the fact that the nature and forms of social capital vary over time.

Despite all this, several studies have addressed the issue. At a macro level of analysis, research by Putman (2000), in relation to the differences observed in social capital in the US, is based on both longitudinal and transversal approximations. His measurements of social capital are based on indices made up of different elements: degree of participation in organizations and the life of citizens, participation in public or voluntary life, informal, social ties and subjective levels of trust between individuals. 
The World Bank has attempted to carry out measurements using surveys. For example, Narayan and Pritchet (1997) designed a measurement instrument used in an empirical study performed in rural Tanzania from data obtained on capital and poverty (SCPS).

Another means of evaluating variations in social capital consists of measuring the absence of social cooperation. Fukujama (1995) attempted to make these measurements via the evolution of certain indirect indicators. These studies suffer from a lack of clarity and moreover, run the risk, at times, of confusing the origins with the consequences.

One of the instruments that has had the greatest repercussion on the measurement of social capital is that of the World Value Survey, carried out by Ronald Inglehart, who gathered data from 43 different societies in order to understand the role of cultural and political factors in economic development. Some researchers into social capital, such Knack and Keefer (1997) demonstrated the existence of a strong relation between generalized levels of trust and levels of investment in 29 countries.

Another measurement instrument is that of the New South Wales Study, developed by Onyx and Bullen (1997). It is a practical means of measurement applied in the state of New South Wales (Australia) in which eight underlying factors were isolated when analyzing the make-up of social capital: participation in the community, proactiveness in the social context, a feeling of trust and security, connections with neighbours, family/friends and work colleagues, tolerance towards diversity and valuing life. Focusing on scores for the social capital of individuals, the authors predict which area individuals belong to.

The Barometer of Social Capital (BARCAS), designed by John Sudarsky (1999), largely based on the WVS and applied in an empirical study in Colombia, functions in two dimensions: social capital and trust in sources of information. Using factorial analyses, he finds eight dimensions included within the factor of social capital: institutional trust, civic participation, rciprocity, horizontal relations, hierarchies, social control civic republicanism and political participation.

Figure 3 shows the key variables considered in studies on the dimensions that make up the construct of social capital.

There are also studies that attempt measurements at an organizational and individual level. The analysis of networks studies the structural aspects of social connections. According to network researchers, the individual is the focus of attention and the reference point. Amongst the most frequently used methods for these approximations is that of saturation and surveys according to name, position or post. The saturation-based approach can only be used in studies of succinct or highly delimited cases, because researchers must be totally familiar with the plan of relations. With regard to large 


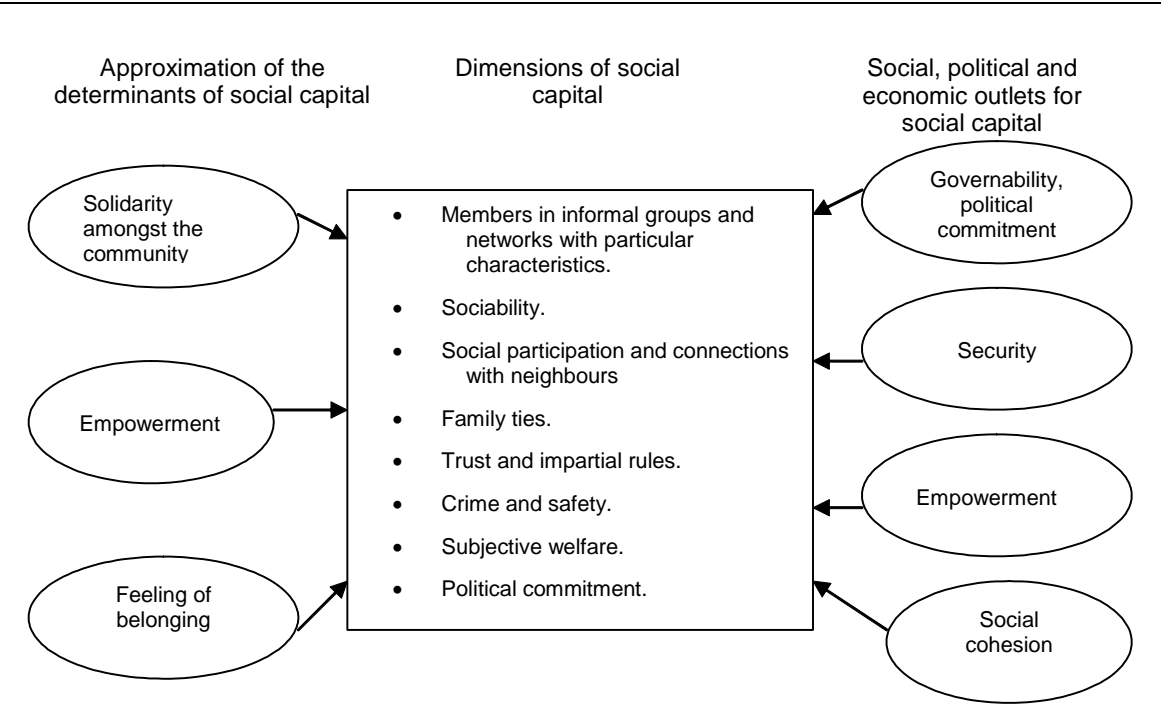

Fig. 3. Key dimensions that make up the construct of social capital. Source: Adapted from Narayan and Casidy (2001, p. 65)

networks, the individual represents the reference point from which diverse personal relationships can be assessed. In the use of the technique of survey by name, individuals are asked to describe their interpersonal ties and relationships, which provide information on the available resources in those networks. The technique of survey by position consists of asking individuals whether they know the people that occupy specific positions or predetermined types of post, adjudged to be important for accessing certain resources in a particular context.

Defenders of the analysis of networks maintain that these approximations are the only means of measuring. As Lin puts it, "without the approximation of social capital to social networks and the resources that go with them, the concept is in danger of evaporating" (2001, p. 23). Detractors claim that the field of interest in network analysis is limited and ignores essential qualitative and contextual dimensions for understanding and explaining social phenomena.

A field where notable advances have been made, thanks to the work of Glaeser et al. (2001), is in assessing the individual investment required for social capital. Researchers analyze the formation of social capital using a mathematical model that allows individual investment decisions to be optimized. Several proposals are put forward in their study (rational investment in social capital is higher in jobs where greater social skills are necessary); social capital decreases in accordance with the likelihood of mobility; people that invest in human capital also normally invest in social capital, etc.). 
These empirical, diverse and contradictory solutions clearly show up a certain weakness in the theoretical framework that could boil down to a circular mode of reasoning that comes close to tautology. As Paldam put it: "... The dream of social capital tells us that social capital is robust. If social capital is as important as it suggests, it would be a good idea for the majority of differing definitions to attach themselves to a 'flowering rock', so that they all address aspects of the same story ..." (2000, p. 631).

Such thoughts make it necessary to continue working on a finding a more homogeneous means of measurement. On his website, Putman ${ }^{1}$ states, "Why measure social capital?: There are three reasons, the first is that measuring social capital will help to make it appear to be more tangible (for those that consider it too abstract); it will also allow us to vindicate investment in social capital, as a model where performance is the main criterion for investment in resources shows that the performance of social capital will increase interest for possible investors; and, lastly, it will show us in what kind of actions are worth investing in for the creation of more social capital".

\section{Social Capital and Competitiveness for Entrepreneurs}

\subsection{Entrepreneurs and Competitiveness}

The study of the entrepreneurial function and the creation of new business can be approached from varying theoretical perspectives (economic, psychological, institutional and managerial; see Fig. 4) (Veciana 1999). Obviously, this chapter is rooted in the socio-cultural or institutional level, dimensionally close to the micro or individual level, i.e., from the perspective of the entrepreneur.

According to Veciana (1999), theories that can be included within the socio-cultural or institutional approach have a solid, common nucleus: "the basic assumption that the decision to run one's own business, and therefore the creation of new firms, is conditioned by external or environmental factors. In other words, it is the socio-cultural factors or the institutional framework that determines entrepreneurial spirit and new firm creation in a given place and time". (1999, p. 21). On an individual or micro level, still within the socio-cultural approach, key researchers mentioned by this author are Birley (1985), Aldrich and Zimmer (1986), Johannisson (1986),

1 See http://www.ksg.harvard.edu/saguaro. 


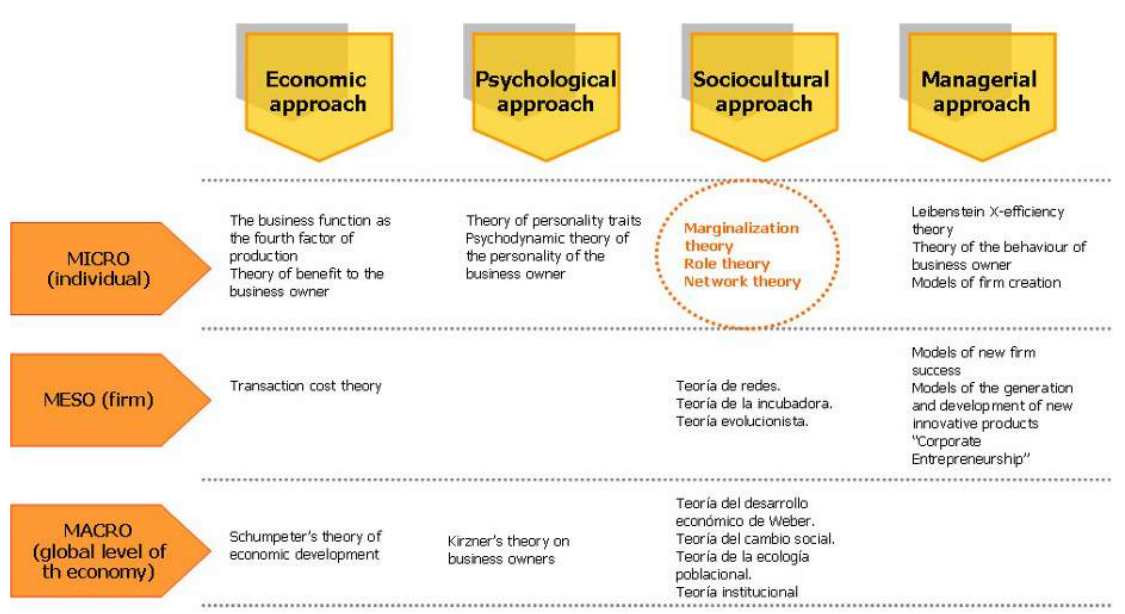

Fig. 4. Theoretical approaches to the entrepreneurial function. Source: Veciana (1999)

Aldrich et al. (1986) and Aldrich et al. (1987). The basic idea is that the entrepreneurial function is inserted and developed within a network of social relationships. New firm creation is enhanced or constrained by a complex labyrinth of relations between the future entrepreneur, available resources and opportunities. This approach is thus of particular interest as it is based more on the idea of cooperation and trust than on competence and distrust.

As a starting point, the entrepreneur can be understood as an individual entrepreneur-business owner of an SME who starts up a project originated from an idea that he/she attempts to impose on the market, driven by a strong centralization and personalization via strategic management. According Aldrich and Zimmer (1986), the phenomenon of new firm creation should be understood as a dynamic process, a function of structures of opportunity and motivated entrepreneurs with access to resources. Therefore, firm creation constitutes a "phenomenon incrusted within networks of continuous social relations" (1986, p. 8) that can enable or hinder the process of firm creation through links between potential entrepreneurs, resources and opportunities.

The omnipresence of the firm's management may help to explain the fact that networks of relations in SMEs are derived from those of the entrepreneur. Indeed, it is thanks to the relations that entrepreneurs maintain with the parties involved that the firm gains access to its first customers, obtains key information, gains access to new markets and looks for the necessary funding for growth and development. In line with these idea, Aldrich and Davis (2000) claim that "under the competitive conditions of 
modern economies, resources directly controlled by owners are insufficient for ensuring the survival and growth of small firms. Consequently, for some opportunities, entrepreneurs need to supplement what they personally control by using social capital" (2000, p. 2).

Therefore, entrepreneurial social capital can be defined as the added value that facilitates the network of relations for the entrepreneur; the relational links that make up their social network. This social capital can be looked at (and therefore measured) at different moments: once at the beginning of the entrepreneurial project or firm (M1), i.e., the entrepreneur's ties and contacts established before starting up the firm, for example, via family or contacts from school/university, or when the firm is up and running; while the firm is carrying out its activities (Mn).

The analysis of M1 is more closely linked to qualitative aspects of the entrepreneurial function, where the success or failure of the entrepreneur does not depend on psychological or personality traits.

The following variables are used by Cuervo (2003) in a similar vein when summarizing the most relevant variables for producing entrepreneurial capabilities: "personal and group characteristics, family and group environments, the values and culture of a society, the institutions and their functioning, the model of training used, the system of science and technology, the actions of the state and the reward system" (2003, p. 57).

Thus, how do entrepreneurs really obtain a competitive advantage?

In an attempt to answer this question, Burt (1992) carried out an analysis of what he calls "structural holes", which exist when complementary resources can be found in places in the network that have weak connections or are unrelated. Those actors (entrepreneurs) who are in a solid position and are capable of connecting them with other sites in the network will enjoy significant competitive advantages, as they are able to construct closer connections, obtain synergy from complementary resources, and build advantages from the productivity that stems from their position. According to Burt, these actors possess sizeable social capital. This is an additional element to the classic Schumpeterian analysis. Schumpeter (1975) claimed that the function of business was to reform or revolutionize the pattern of production by exploiting an invention. The more entrepreneurs can act in an innovative way, the more they can take advantage of the structural holes and turn them into opportunities for their entrepreneurial projects.

The idea that entrepreneurial opportunities (which generally refer to the absence or excess of demand for a particular product) are to be found in gaps that exist in the market is not a new one. However, economic theory offers scarce explanation for the variety and performance of each entrepreneurial project. For example, why do some successfully initiate and maintain a new firm while others fail? In Burt's theory in relation to structural 
holes, he puts forward the following explanation: "much of competitive behaviour and its outcomes can be understood in terms of the access of particular locations to those holes... in the competitive arena. This is why structural holes are entrepreneurial opportunities for accessing information, coordination and control. Entrepreneurs who manage to gain access to a variety of social connections probably enjoy a higher level of structural autonomy and competitive advantage". (1992, p. 12). If we consider three players: A, B, and the entrepreneur, the entrepreneur will be in a structural hole when the three following conditions are present: (1) A and B have no direct contact with each other; (2) A and B possess different types of information; (3) the entrepreneur has contacts with both A and B. The entrepreneur acts by bringing demands and preferences into conflict and constructs value from that discord (Burt 1992, p. 34).

The role of networks and the establishment of a network have also been adopted as a means of understanding entrepreneurial behaviour, both at the start-up stage of new firms (Aldrich and Zimmer 1986), and in their subsequent development and growth. Johannisson (1986) proposed a paradigm in the establishment of a network and the process of starting up a new firm: entrepreneurial behaviour in establishing a network is likely to affect the potential success of the firm.

Figure 5 shows the three dimensions of the analysis of networks (availability, and diversity; nature; quality of links) that an analysis of the literature on this concept clearly shows in regard to measuring its extent (Batjargal 2001; Burt 1997; Nahapiet and Ghoshal 1998; Lai et al., 1998).

Researchers have attempted to explain the performance of entrepreneurial projects from the viewpoint of the behaviour of diverse factors (the strategy chosen, characteristics of the sector, characteristics of the start-up) but the importance of the role of the entrepreneur in a firm's success has also been observed from two other standpoints; from an individualist and a social perspective (Alizadeh 2000). In addition, March and Sutton (1997) analyze the different ways of measuring performance (in comparison to growth in investment, operating margins or the reinvestment of assets).

Moreover, some research on job markets (Granovetter 1973; Lin and Dumin 1986), has shown that the larger an individual's network of relations, the greater professional success they may attain (measured in terms of pay, power and mobility). Using analogous reasoning, the possession of a wide-reaching network of relations could enhance the firm's performance, insofar as entrepreneurs with numerous contacts can establish relations with their customers more easily, as well as neutralizing, to a certain extent, their negotiating power. The use of large social networks allows them to reduce transaction costs, fundamentally when accessing information, in negotiations and in decision-making. 
Three dimensions that permit measurement (Buró, 1997; Lai, 1998:

Naphiet \& Ghoshal, 1998 and Batjargal, 2001)
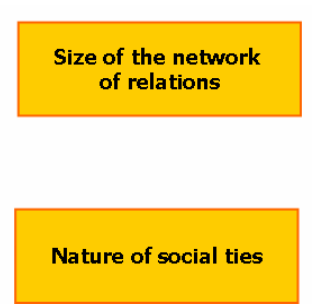

Privacy of interpersonal social relations associated with weak and strong ties. Granoveter, 1973; Lin 1995

Fig. 5. Summary of the analysis of the dimensions of networks. Source: Author's own work

Several proposals can be made on work from this theoretical framework that relate the performance of a start-up with the social capabilities of the entrepreneur, two fundamental questions in research that support the idea of the use of entrepreneurial social capital in the functioning and success of projects. Our first proposal would be:

P1: The larger the networks possessed by entrepreneurs, the greater their chances of reaching improved performance in their business projects.

The theory of social networks has also shown the existence of a positive relation between the professional success of individuals and the quality of their social ties. Quality, in this case, refers to connections found within the organization with sound ties (Lin and Dumin 1986). In the case of entrepreneurs, maintaining quality social relationships also enables them to take action to improve access to markets and to financing, and may even help to enhance the firm's name and image.

We can thus put forward a new proposal:

P2: In cases where entrepreneurs possess quality social links, i.e. a large number of people in important positions, their entrepreneurial projects will perform better.

In any business project, access to external resources represents one of the most common obstacles. The accumulation of such resources allows available, productive opportunities to be exploited in the environment and provides a more satisfactory safeguard against threats (Yli-Renko et al., 2000). From among the external resources within the reach of SMEs, those which commonly entail the most difficulty are access to funding and access to information. 
With regard to the access of information, external resources are widely recognized as a determinant of competitiveness in any firm, though it is also recognized that for SMEs, and even more so for the projects they start up, they represent one of the major weaknesses.

In this sense, the benefits of social capital for accessing information have been widely discussed in the literature on social networks and social capital. As Adler and Kwon state, "...for the actor, social capital enables access to wide-reaching sources of information at less cost, providing quality, relevant, opportune information". (2002, p. 14). Brüdler and Preisendörfer claim that "... social relations and social contacts are important channels for accessing information... information received through established links in social relations is often more useful, reliable, exclusive and less redundant" (1998, p. 214)

We view an entrepreneur's social network as being of utmost importance in bestowing competitive advantage insofar as it allows the entrepreneur access to key, privileged information and endows it with value. We can thus formulate the following proposal:

P3: The larger an entrepreneurs network of relations, the more access he/she will have to sources of information.

Access to information on the part of the entrepreneur and his/her social relations can be linked to the theory contributed by Granovetter (1973) on strong and weak ties. The logic behind this theory is based on the fact that, when the relationship between two people is strong, (strong ties), there is a high possibility that these people will know the same type of individuals and will therefore possess the same information. On the other hand, weak ties increase the likelihood that an individual can gain access to people with different interests and other kinds of knowledge. Weak ties pave the way for fresher, more unique information than strong ties, where redundant information often abounds.

We can therefore put forward another proposal:

P4: Entrepreneurs that have access to better information are those that possess numerous weak ties among their social relations.

It has already been stressed that, among the external resources that the entrepreneur needs to procure are access to information and sources of funding. Entrepreneurs can use social networks to access this type of resource. Some studies have gone as far as to show the beneficial effects for entrepreneurs of having social relationships with bankers (Uzzi 1997), which could fundamentally come under the umbrella of relationships of trust. We can thus propose that:

P5: Strong ties allow better access to financial resources than weak ones. 


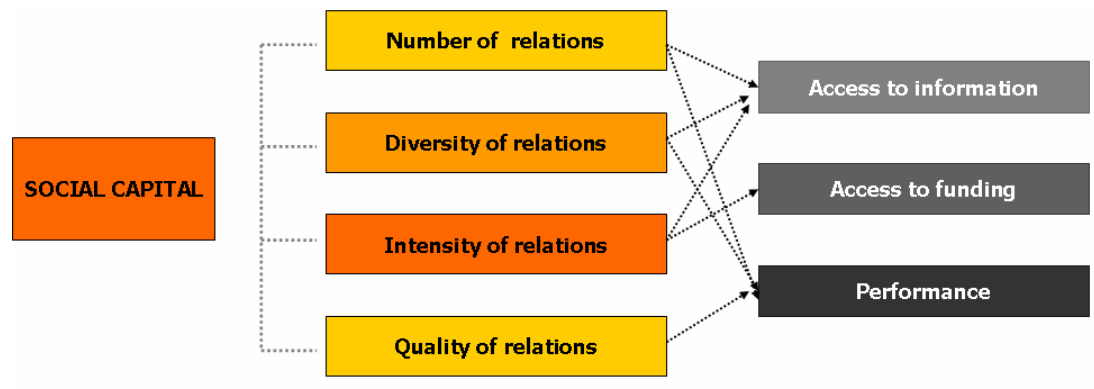

Fig. 6. Conceptual model. Source: Author's own work

The group of proposals we have presented herein can be interconnected as shown in the Fig. 6.

\section{Conclusions}

Using a review of the literature, in this study, we have carried out an extensive analysis of the concept of social capital. This analysis has allowed us to ascertain that social capital can be viewed from a macro perspective, (in the framework of social structure) all the way down to an individual level, via organizational and institutional levels.

The study attempts to make progress in the stream of research that considers a theoretical approximation to the value of social capital in management science using up-to-date literature on social capital and value creation. The outcomes of empirical studies in the field and on interfirm and intrafirm relations have also been taken into account.

It can be concluded that the possession of social capital is an important element when generating a competitive advantage that allows the entrepreneur to give shape to entrepreneurial projects with sound business performance. This is why the performance of these projects does not depend solely on strategies, product quality, or the gaps they will attempt to bridge in the market, but also on the social capital they possess in order to give the new firm the necessary drive. The entrepreneur's capacity to build a fertile, wide-reaching network of social relations allows him/her to complement the physical and intellectual capital they may possess.

\section{References}

Adler, P., Kwon, S. (2002). Social capital: prospects for a new concept. Academy of Management Review, 27, 17-40.

Aldrich, H., Davis, A. (2000). The organizational advantage? Social capital, gender and access to resources. http://www.unc.edu/ healdric/workpapers/wp132.pdf. Accessed 10 September 2005. 
Aldrich, H., Zimmer, C. (1986). Entrepreneurship through social networks. In: Sexton D., Smilor R. (Eds.), The Art and Science of Entrepreneurship, pp. 3-23. Cambridge: Ballinger.

Aldrich, H. E. et al. (1986). Social behavior and entrepreneurial networks. Frontiers of Entrepreneurship Research. Babson College.

Aldrich, H. E. et al. (1987). The impact of social networks on business foundings and profit: a longitudinal study. Frontiers of Entrepreneurship Research. Babson College.

Alizadeh, Y. (2000). Unravelling small business owner/manager's networking activities, http://www.sbaer.uca.edu/research/icsb/2000/icsb/pdf/56.pdf. Accessed 10 September 2005.

Arrow, K. (2000). Observation on social capital. In: Dasgupta, P. (Ed.), Social Capital: A Multifaceted Perspective. New York: World Bank.

Batjargal, B. (2001). Social capital and entrepreneurial performance in Russia: A longitudinal study. Organization Studies, 24, 535-556.

Batjargal, B. (2003). Social capital and entrepreneurial performance in Russia: A longitudinal study. Organization Studies, 24(4), 535-556.

Belliveau, M., O Reilly, C., Wade, J. (1996). Social capital at the top: effects of social similarity and status on CEO compensation. Academy of Management Journal, 39, 1568-1594.

Birley, S. (1985). The role of networks in the entrepreneurial process. Journal of Business Venturing, 1(1), 107-117.

Bolino, M., Turnley, W., Bloodgood, J. (2002). Citizenship behavior and the creation of social capital in organizations. Academy of Management Review, 27, 505-522.

Bourdieu, P. (1986). The forms of capital. In: Richardson, J. (Ed.), Handbook of Theory and Research for the Sociology of Education. New York: Greenwood.

Brüdler, J., Preisendörfer, P. (1998). Network support and the success of newly founded business. Small Business Economics, 10, 213-225.

Burt, R. (1992). Structural Holes: The Social Structure of Competition. Cambridge: Harvard University Press.

Burt, R. (1997). The contingent value of social capital, Administrative Science Quaterly, 42, 339-365.

Burt, R. (2001). The network structure of social capital. In: Sutton, R., Staw B. (Eds.), Research in Organizational Behavoir, vol. 22. Greenwich: JAI.

Coleman, J. (1988). Social capital in the creation of human capital. American Journal of Sociology, 94, 95-120.

Coleman, J. (1990). Foundations of Social Theory. Cambridge: Belknap.

Cuervo, A. (2003). La creación empresarial: De empresarios y directivos. In "Entrepreneurship: Homage to profesor Jose Maria Veciana". Universidad Autoçonoma de Barcelona, Barcelona. P. 49-73.

Dasgupta, P. (2000). Social capital: a multifaceted perspective. New York: World Bank.

Deeds, D.L., Hill, C.W.L. (1996). Strategic alliances and the rate of new product development: An empirical study of entrepreneurial biotechnology firms. Journal of Business Venturing. 11(1), 41-55. 
Fukuyama, F. (1995). Trust: The Social Values and the Creation of Prosperity. New York: The Free Press.

Glaeser, M., Laibson, D., Scheinkman, J., Soutter, C. (2000). Measuring trust. The Quaterly Journal of Economics, 811-846.

Glaeser, M., Laibson, D., Sacerdote, B. (2001). The economic approach to social capital. Working Paper Harvard Institute of Economic Research, No. 7728. Cambridge: Harvard Institute of Economic Research.

Goes, J.B., Park, S.H. (1997). Interorganizational links and innovation: The case of hospital services. Academy of Management Journal. 40(3), 673-696.

Granovetter, M. (1973). The strength of weak ties. American Journal of Sociology, 78, 1360-1380.

Grootaert, C., Van Bastelaer, T. (2002). Understanding and Measuring Social Capital: A Multi-Disciplinary Tool for Practitioners. Washington DC: The World Bank.

Hanifan, L. J. (1916). The rural school community center. Annals of the American Academy of Political and Social Science, 67, 130-138.

Ibarra, H. (1995). Race, opportunity and diversity of social circles in managerial networks. Academy of Management Journal, 38, 673-703.

Johannisson, B. (1986). Networking strategies: management, technology and change. International Small Business Journal, 5, 19-30.

Knack, S., Keefer, P. (1997). Does social capital have an economic payoff ? a cross country investigation? The Quarterly Journal of Economics, 112, 1251-1289.

Leana, C., Van Buren, J. (1999). Organizational social capital and employment practices. Academy of Management Review, 24, 538-555.

Lin, N. (2001). Social Capital: A Theory of Social Structure and Action. Cambridge: Cambridge University Press.

Lin, N., Dumin, M. (1986). Access to occupations through social ties. Social Networks, 8, 365-385.

Lin, N., Ensel, W., Vaughn, R. (1981). Social resources and strength of ties: structural factors in occupational status attainment. American Sociological Review, 46, 393-405.

March, J., Sutton, A. (1997). Organizational performance as a dependent variable. Organization Science, 8, 698-706.

Nahapiet, J., Ghoshal, S. (1998). Social capital, intellectual capital and the organizational advantage. Academy of Management Review, 23, 242-266.

Narayan, D., Pritchett, L. (1997). Cents and Sociability: Household Income and Social Capital in Rural Tanzania, World Bank, Washington DC, USA.

Narayan, D., Casidy, M. (2001). A dimensional approach to measuring social capital: development and validation of a social capital inventory. Current Sociology, 49, 59-102. 
Onyx, J., Bullen, P. (1997). Measuring social capital in five communities. CACOM Working Paper Series No. 41. Sydney: University of Technology.

Paldam, M. (2000). Social capital: one or many? Definition and measurement. Journal of Economics Surveys, 14, 629-653.

Portes, A. (1998). Social capital: Its origins and applications sociology. In: Lesser, E. (Ed), Knowledge and Social Capital: Foundations and Applications, pp. 43-67. Boston: Butterworth-Heinemann.

Putman, R. (1993). The prosperous community. Social capital and public life. The American Prospect, 4, 35-42.

Putman, R. (1995). Bowling alone: America's declining social capital. Journal of Democracy, 6, 65-78.

Putman, R. (2000). Bowling Alone: The Collapse and Revival of American Community. New York: Simon \& Schuster.

Putman, R., Leonardi, R., Nanetti, R. (1993). Making Democracy Work, Civic Traditions in Modern Italy. Princeton: Princeton University Press.

Schumpeter, J. (1975). Capitalism, Socialism and Democracy. New York: Harper and Row.

Shan, W., Walter, G., Kogut, B. (1994). "Inter-firm cooperation and start-up innovation in the biotechnology industry", Strategy Management Journal, 15, 387-394.

Singh, K. (1997). The impact of technology complexity and interfirm cooperation on business survival. Academy of management Journal. 40(2), 339-357.

Sudarsky, J. (1999). "El Capital Social de Colombia: La Medición Nacional con el BARCAS (Barómetro del Capital Social)". Archivos de Macroeconomía, 122. World Bank.

Solow, R. (2000). Notes on social capital and economic performance. In: Dasgupta, P. (Ed.) Social Capital: A Multifaceted Perspective. New York: World Bank.

Tsai, W., Ghoshal, S. (1998). social capital and value creation: the role of intrafirm networks. Academy of Management Journal, 41, 464-476.

Uzzi, B. (1997). Social structure and competition in interfirm networks: The paradox of embeddedness. Administrative Science Quarterly, 29, 598-621.

Veciana, J. (1999). Creación de empresas como programa de investigación científica. Revista Europea de Dirección y Economía de la Empresa, 8, 11-36.

Walker, G., Kogut, B., Shan, W. (1997). Social capital, structural holes and the formation of the industry network. Organization Science, 8, 109-125.

Yli-Renko, H.K. (1999). Dependence, Social Capital and Learning in Key Customer Relationships: Effects on the Performance of Technology-Based New Firms. Acta Polytechnica Scanidnavica, Industrial Management and Business Administration Series, Finnish Academy of Technology.

Yli-Renko, H., Autio, E., Sapienza, H. (2000). Social capital, relational learning and knowledge distinctiveness in technology based new firms. http:// www.babson.edu/entrep/fer/papers99/XXVIII/XXVIII_D/XXVIII_Dtext.htm. Accessed 1 September 2005.

Zaheer, A., McEvily, B., Perrone, V. (1998). Does trust matter? Exploring the effects of interorganizational and interpersonal trust on performance. Organization Science. 9(2), 141-159. 